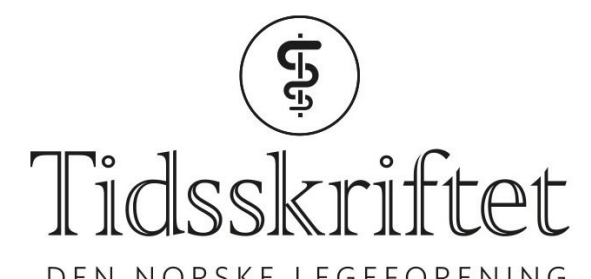

DEN NORSKE LEGEFORENING

\title{
Bidrag til den ultimate kollasjen
}

ANMELDELSER

TROND TRATTEBERG SERKLAND

Lege i spesialisering i klinisk farmakologi, Haukeland universitetssjukehus

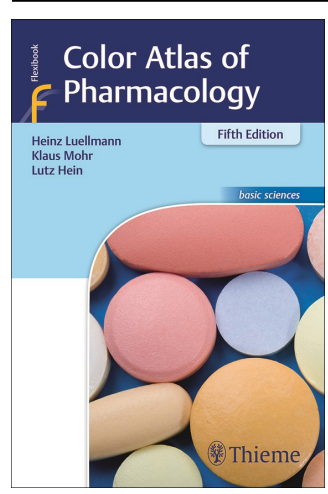

Heinz Luellmann, Klaus Mohr, Lutz Hein

Color Atlas of Pharmacology

5. utg. 444 s, tab, ill. Stuttgart: Thieme, 2017. Pris EUR 45

ISBN 978-3-13-241065-7

Dette er den femte engelske utgaven av Luellmann's Color Atlas of Pharmacology, et konsept som nylig feiret 25-årsjubileum. Prosjektets uttalte mål er at "pharmacological principles be understood, and not just memorized» og leseren skal «make sense of the facts». Den er skrevet for studenter innen medisin, odontologi, farmasi og andre som måtte være interessert i legemidler og bruken av dem.

Boken er delt i tre deler, der den første tar for seg generelle farmakologiske prinsipper. Den andre, som omfatter rundt halvparten av boken, er inndelt etter hvor legemidler virker og noe etter hvilken virkningsmekanisme de har, og den siste delen omtaler utvalgte sykdomsgrupper.

Gjennom hele boken er den venstre siden fylt med tekst, mens den høyre er fylt med illustrasjoner. Og det er nettopp illustrasjonene som skaper begeistring hos meg. Mange av dem klarer å konkretisere dette fascinerende fagfeltet, som omhandler hvordan kroppen forholder seg til det kroppsfremmede. De gir et håndgripelig bilde av viktige molekyler som vi omgås og hvordan de påvirker oss: En kniv inn i et valmuehode, aerosoler som strømmer inn til glatt muskulatur i luftveiene, malerier produsert under LSD-påvirkning, elektronmikroskopiske bilder av hepatocytter som metaboliserer fenobarbital, en pil med kurare, strukturformler satt i sammenheng. 
Alle illustrasjonene er ikke like gode og fargene er til tider i overkant blasse. Boken er laget for å bære med seg, noe som gjør at enkelte av illustrasjonene oppleves å være forminsket for mye. Jeg savner en elektronisk løsning der man kan logge seg inn og få tilgang til bildene. Utvalget av sykdomsgrupper i tredje del kan også virke noe tilfeldig.

Men, når det er sagt, dette er bok som anbefales. Fra tyske kilder i avdelingen kan jeg bekrefte at den oppleves som nyttig også for erfarne overleger. Den inneholder ikke «Figuren med stor F», men flere gode kandidater til den ultimate kollasjen, spør du meg. Og det er ingen forsøk på noen plutselig penis (1).

\section{LITTERATUR:}

1. Westin AA. Plutselig penis. Tidsskr Nor Legeforen 2014; 134: 2311. [CrossRef]

Publisert: 3. september 2018. Tidsskr Nor Legeforen. DOI: 10.4045/tidsskr.18.0243

(C) Tidsskrift for Den norske legeforening 2020. Lastet ned fra tidsskriftet.no 